\title{
Colletotrichum gloeosporioides: A True Endophyte of the Endangered Tree, Cynometra travancorica in the Western Ghats Thulasi G Pillai ${ }^{* *}$ and Jayaraj $\mathbf{R}^{2}$
}

${ }^{1}$ Department of Forest Pathology, Kerala Forest Research Institute, Peechi, Thrissur-680751, India

${ }^{2}$ Divisions of Forest Ecology and Biodiversity Conservation, Kerala Forest Research Institute, Peechi, Thrissur-680751, India

\begin{abstract}
Fungi form symbiotic associations with forest trees. True endophytes have been evolving with the host trees millions of years. Study was carried out to isolate and identify true endophytic fungi from the leaves of a rare tree species of Fabaceae family, Cynometra travancorica. Study was conducted in trees growing in four different forest areas of South Western Ghats in three different seasons, pre-monsoon, monsoon and post-monsoon. Twelve fungal cultures were obtained and one of the cultures was common in all the samples. Partial sequencing of genomic DNA was done for identification. The endophyte was identified as Colletotrichum gloeosporioides. This is the first report of Colletotrichum gloeosporioides as endophyte from C. travancorica. This organism can have an important role in the survival and protection of the tree against harsh environment and adverse conditions. Under favorable conditions, chances of the conversion of $C$. gloeosporioides as an endophyte to pathogen cannot be ruled out.
\end{abstract}

Keywords: Fungal endophyte; Cynometra travancorica; Western ghats; Colletotrichum gloeosporioides

\section{Introduction}

Plants form symbiotic associations with endophytic fungi which live inside healthy tissues as dormant microthalli. Studies conducted during the last 30 years have shown that presence of endophytic fungi is ubiquitous [1]. Endophytes can help the host plant by producing a surplus of substances that provide protection and survival. The metabolites from the endophytic fungi can have potential for use in modern medicine, agriculture, and industry [2]. Antibiotics, antimycotics, immunosuppressants, and anticancer compounds are only a few examples. Isolation of rohitukine, a chromane alkaloid possessing anti-cancer activity was reported from Fusarium proliferatum [3]. The diversity and quantity of endophytes depends on biotic, abiotic, and experimental factors like host species, type and phase disposition of plant organ, edaphic and climatic conditions, isolation procedure and number and size of samples [1]. Fungal endophytes in tropical forest trees are less studied, where abundance and diversity are great. The Western Ghats, especially the southern parts is one of the richest bio-geographic provinces of the Indian subcontinent Cynometra travancorica is an endangered tree species of the family Fabaceae [4]. The timber is useful and it is grown as avenue tree [5]. The tree is rare and endemic to Southern Western Ghats. The plant is rarely seen and narrowly distributed in evergreen and semievergreen forest of Southern Western Ghats. In the present study our aim was to isolate and identify the true fungal endophyte present in the leaves of Cynometra travancorica.

\section{Materials and Methods}

\section{Sample collection}

The material was collected from 4 different evergreen forest - Shendurney (8 8727 N, 771634 E), Siruvani ( $7^{\circ} 10$ N, 1055’ E), Thamarassery Ghat $\left(11^{\circ} 26^{\prime} \mathrm{N}, 7553 \mathrm{E}\right)$ and Vellanimala $\left(10^{\circ} 25 \mathrm{~N}\right.$ and $76^{\circ} 30 \mathrm{E}$ ) of Kerala. The collection was made in 3 different season, pre monsoon, monsoon, post monsoon. Three samples per location per season were collected for the analysis.

\section{Isolation of endophytes}

Isolation of fungal endophyte was done as per standard procedures
Kharwar et al. [6], with slight modifications. The leaves were surface sterilized with $75 \%$ ethanol for 90 seconds. The tissues were rinsed in sterile distilled water 3 times and allowed to surface dry in sterile conditions. Three trees were selected from a site. Five different media were used for fungal isolation.

- Potato dextrose agar (PDA)

- Sabouraud's dextrose agar

- PDA with Rose Bengal

- Water agar and

- Oat Meal Agar.

Oat Meal Agar was found to give optimum growth for fungal isolation (rapid growth and more number of colonies) and was selected for further study. Five segments of leaves with $0.5 \mathrm{~cm}$ diameter were evenly placed in each petri dishes containing Oat Meal Agar with streptopenicillin, to suppress bacterial growth and incubated for 20 days with $12 \mathrm{hrs}$. of light followed by $12 \mathrm{hrs}$. of dark cycles at room temperature. A total of 40 segments were analyzed. The tissues were monitored every day to check growth of endophytic fungal colonies. The hyphal tips when grew out from leaf segments were isolated, subcultured and stored at $-4^{\circ} \mathrm{C}$ on Oat Meal Agar slants for preservation. The cultures were screened for the true endophytic fungi. The isolates were maintained by routine sub culturing. Identification was done by partial sequencing of genomic DNA.

*Corresponding author: Thulasi G Pillai, Department of Forest Pathology, Kerala Forest Research Institute, Peechi, and Thrissur-680751, India, Tel: +91-4872690100; E-mail: thulasigpillai@gmail.com

Received October 14, 2014; Accepted October 18, 2014; Published October 22, 2014

Citation: Pillai TG, Jayaraj R (2015) Colletotrichum gloeosporioides: A True Endophyte of the Endangered Tree, Cynometra travancorica in the Western Ghats. J Plant Pathol Microb 6: 267. doi:10.4172/2157-7471.1000267

Copyright: (c) 2015 Pillai TG, et al. This is an open-access article distributed under the terms of the Creative Commons Attribution License, which permits unrestricted use, distribution, and reproduction in any medium, provided the original author and source are credited. 
Citation: Pillai TG, Jayaraj R (2015) Colletotrichum gloeosporioides: A True Endophyte of the Endangered Tree, Cynometra travancorica in the Western Ghats. J Plant Pathol Microb 6: 267. doi:10.4172/2157-7471.1000267

Page 2 of 5

\section{Analysis of data}

Frequency of occurrence of endophytes (\%): Fungal population was quantified as frequency of occurrence. It is calculated as follows

[No of leaf discs colonised by a given fungus/Total number of explants observed] x 100 [7].

\section{Colonisation rate}

Colonization rate (CR) was calculated as the total number of leaf segments infected by fungi divided by the total number segments incubated [8]. Colonization rate was expressed as percentages, as widely used in the past endophyte studies, therefore, colonization rates can be used for comparative purposes.

[Total numbers of explants in a sample yielding 1 isolate or more/ Total number of leaf segments in that sample] x 100 [8].

Isolation rate: Isolation rates are used to demonstrate the degree of multiple colonization from the samples in different trials.

Isolation rate is determined by Frohlich et al. [9].

[Total number of isolates yielded by a given sample/Total number of explants in that sample].

Identification of fungal endophyte: Macro morphological characters were recorded. The culture failed to sporulate. The culture was further refined by partial sequencing of endophytic genome.

DNA Isolation: Genomic DNA was extracted from pure endophytic culture using Sigma Aldrich DNA extraction Kit. D1/D2 region of LSU (Large subunit 28S rDNA) gene was amplified by Polymerase Chain Reaction (PCR) from the isolated genomic DNA. DNA sequencing was carried out with PCR amplicon. D1/D2 region was amplified by PCR from fungal genomic DNA using universal Primers [10].

F- 5'-ACCCGCTGAACTTAAGC-3', $\quad \mathrm{R}$ - 5'-GGTCCGTGTTTCAAGACGG-3'. PCR was carried out in a final reaction volume of $25 \mu \mathrm{l}$ with deionized water $17.0 \mu \mathrm{l}$, Taq buffer without $\mathrm{MgCl}_{2}(10 \times)$ $2.5 \mu \mathrm{l}, \mathrm{MgCl}_{2}(15 \mathrm{Mm}) 1.0 \mu \mathrm{l}$, Forward Primer $(10 \mathrm{pm} / \mu \mathrm{l}) 0.5 \mu \mathrm{l}$, Reverse Primer $(10 \mathrm{pm} / \mu \mathrm{l}) 0.5 \mu \mathrm{l}$, dNTPs $1.0 \mu \mathrm{l}$, Taq DNA Polymerase $(5 \mathrm{U} / \mu \mathrm{l})$ $0.5 \mu \mathrm{l}$, Template DNA(20 ng/ $\mu \mathrm{l}) 2.0 \mu \mathrm{l}$ to a final volume of $25.0 \mu \mathrm{l}$. The PCR protocol designed for 30 cycles for the primers used were Initial denaturation $95^{\circ} \mathrm{C} 5$ minutes, Denaturation $94^{\circ} \mathrm{C} 30$ seconds, Annealing $48^{\circ} \mathrm{C} 30$ seconds, Extension $72^{\circ} \mathrm{C} 45$ seconds, Denaturation $94^{\circ} \mathrm{C}$ 30 seconds, 5 Final Elongation $72^{\circ} \mathrm{C} 10$ minutes. Commercially available 100 bp ladder was used as standard molecular weight DNA. PCRProduct Electrophoresis was carried out. Amplified PCR product was purified using column purification as per manufacturer's guidelines, and further used for sequencing reaction (Figures 1 and 2) The concentration of the purified DNA was determined and was subjected to automated DNA sequencing on ABI3730xl Genetic Analyzer (Applied Bio systems, USA). The Sequencing was done at UniBiosys Biotech Research Labs, Kochi, and Kerala, India. The sequences after editing were then used for similarity searches using BLAST (Basic Local Alignment Search Tool) programme in the NCBI, USA GenBank (www.ncbi.nlm. nih.gov) DNA database for identifying the fungal strains.

\section{Results}

\section{Isolation rate/colonization rate/frequency of occurrence of endophytes}

About 12 pure cultures were obtained from the leaves of Cynometra travancorica. The leaf cultures constantly yielded one white fungus which was identified as C. gloeosporioides. The culture was identified as C. gloeospoiroides. The frequency, colonization rate and isolation rate were good (Table 1 and Figures 1-5).

\section{Sequencing of D1/D2 region of LSU (Large Subunit $28 S \mathbf{r}$ DNA)}

Sequenced data of D1/D2 region of LSU (Large Subunit $28 \mathrm{~S} r$ DNA) after subjecting to BLAST with the nrd database of NCBI gene bank database revealed that the organism was Colletotrichum gloeosporioides with $100 \%$ similarity with accession number AB710144.1. Our accession number is KM823608.

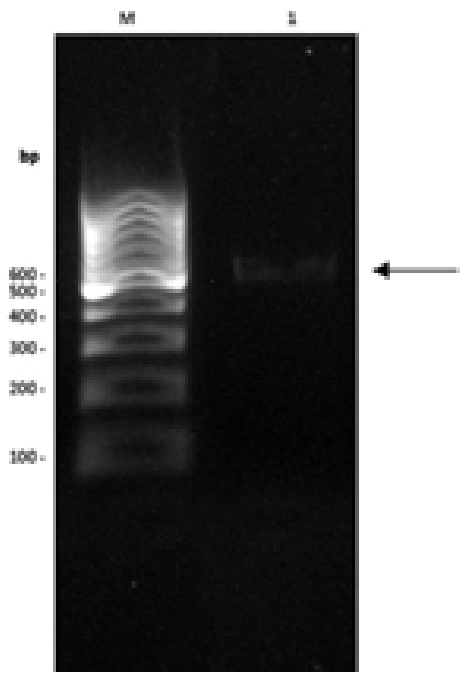

Figure 1: Agarose gel showing PCR amplification. M.DNA size marker of $100 \mathrm{bp}$, Lane one is amplified DNA from the fungus.

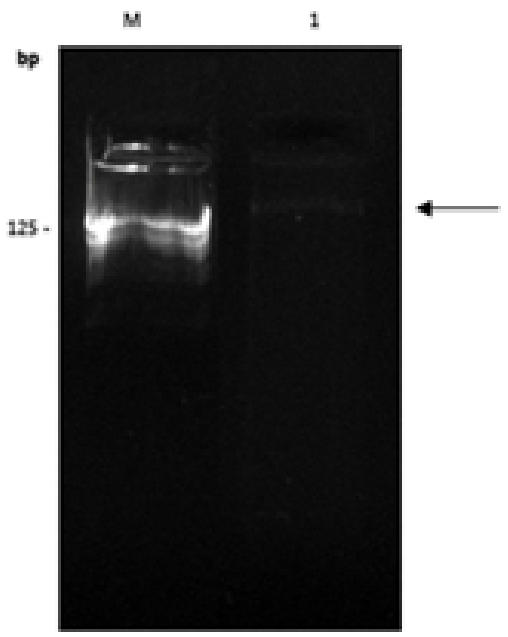

Figure 2: Agarose gel showing the PCR-amplified rDNA with Eco R1 Hind III double digest marker $125 \mathrm{bp}$.

\begin{tabular}{|c|c|c|c|}
\hline Plant & $\begin{array}{c}\text { Frequency of } \\
\text { occurrence of } \\
\text { endophytes (Value-\%) }\end{array}$ & $\begin{array}{c}\text { Colonisation rate } \\
\text { (Value-\%) }\end{array}$ & $\begin{array}{c}\text { Isolation rate } \\
\text { (Value-\%) }\end{array}$ \\
\hline $\begin{array}{c}\text { C. travancorica } \\
\text { leaves }\end{array}$ & 70.6 & 86.6 & 80 \\
\hline
\end{tabular}

Table 1: Isolation rate of the fungal endophytes from C. travancorica. 
Citation: Pillai TG, Jayaraj R (2015) Colletotrichum gloeosporioides: A True Endophyte of the Endangered Tree, Cynometra travancorica in the Western Ghats. J Plant Pathol Microb 6: 267. doi:10.4172/2157-7471.1000267

Page 3 of 5

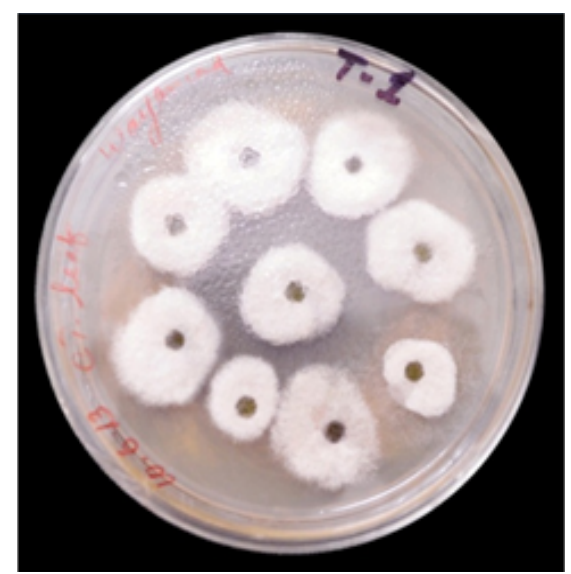

Figure 3: Isolation of funal endophytes obtained from the leaves of Cynometra travancorica on Oat meal agar. Colonisation of fungal and endophytes on leaf segments of C. travancorica.

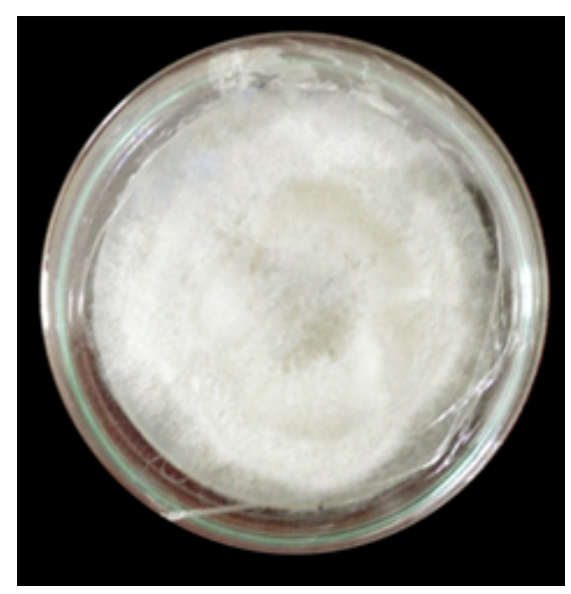

Figure 4: Pure culture of C. gloeosporiodes.
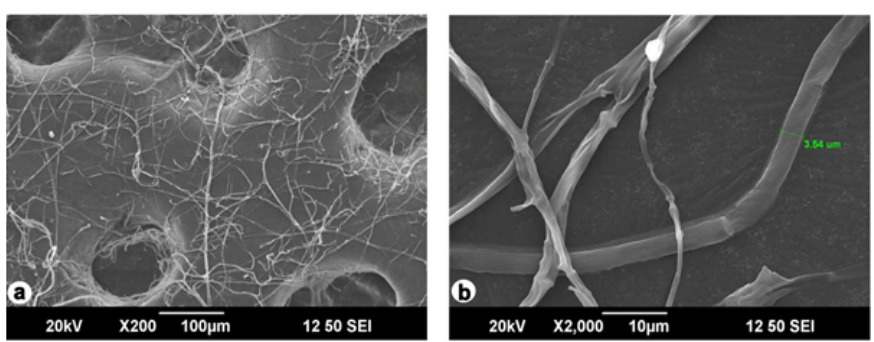

Figure 5: Scanning electron microscope image of mycelium of $C$. gloeosporiodes a. Mycellium, b. hyphae.

\section{Sequence Data sample A FP}

Sequence Data FP

GCAAGGATGCTGGCATAATGGTCATCAGCGA

Sequence Data RP

ATCCTTGCGGAGCGCGTACCTCAGCCCGCCGAAGGGTAT

TATGCAACAGGCTATAACACTCCCCGAAGAGAGCT
ACGTTCCTGAAGCTTTTGTCCCCGACAGCGAGCTGATGC

TGGCCTGAGCCGGCGAAGTGCCCCAGCCGCGAGAG

CTGGGTGATTCACCGGACGCAAGTCTGGTCACAAGCGCT

TCCCTTTTAACAATTTCACGTGCTGTTTAACCCTC

TTTTCAAAGTGCTTTTCATCTTTCGATCACTCTACTTGTG

CGCTATCGGTCTCTGGCCGGTATTTAGCTTTAGA

AGAAATATACCTCCCATTTTGAGCAGCATTCCCAAACTA

CTCGACTCGTCGAAGGAGCTTTACAAAGGCTTGGT

GTCCAACTGTACGGGGCTCTCACCCTCTCTGGCGTCCCG

TTCTAGGGAACTTGGAAGGCACCGCACCAAAAGCA

TCCTCTGCAAATTACAACTCGGGCCTAGGGCCAGATTTC

AAATTTGAGCTGTTGCCGCTTCACTCGCCGTTACT

GAGGCAATCCCTGTTGGTTTCTTTTCCTCCGCTTATTGAT

Consensus Sequence Data

ATCAATAAGCGGAGGAAAAGAAACCAACAGGGATTGCC

TCAGTAACGGCGAGTGAAGCGGCAACAGCTCAAATT

TGAAATCTGGCCCTAGGCCCGAGTTGTAATTTGCAGAGG

ATGCTTTTGGTGCGGTGCCTTCCAAGTTCCCTAGA

ACGGGACGCCAGAGAGGGTGAGAGCCCCGTACAGTTGG

ACACCAAGCCTTTGTAAAGCTCCTTCGACGAGTCGA

GTAGTTTGGGAATGCTGCTCAAAATGGGAGGTATATTTC

TTCTAAAGCTAAATACCGGCCAGAGACCGATAGCG

CACAAGTAGAGTGATCGAAAGATGAAAAGCACTTTGAAA

AGAGGGTTAAACAGCACGTGAAATTGTTAAAAGGG

AAGCGCTTGTGACCAGACTTGCGTCCGGTGAATCACCCA

GCTCTCGCGGCTGGGGCACTTCGCCGGCTCAGGCC

AGCATCAGCTCGCTGTCGGGGACAAAAGCTTCAGGAACG

TAGCTCTCTTCGGGGAGTGTTATAGCCTGTTGCAT

AATACCCTTCGGCGGGCTGAGGTACGCGCTCCGCAAGGA

TGCTGGCATAATGGTCATCAGCGA

\section{Discussion}

Endophytic fungal association with forest trees are always nonpathogenic [1]. The concept of "true endophyte" has been proved in our study. True endophytes are those fungi whose colonisation never results in visible disease symptoms [11]. Endophytic fungi on leaves of forest trees play ecological roles as accepted mutualists [12], latent pathogens [1] and saprobic decomposers after leaf death [13,14]. Out of the twelve cultures obtained, Colletotrichum gloeosporioides was isolated from Cynometra travancorica in all the three seasons studied and from all the four locations. An endophyte which is in association with a plant in all the conditions despite the climatic and geographical variations is true endophyte. Most of the endophytic cultures are sterile, making morphology based identification difficult. Earlier reports suggest that endophytes possess traits which are advantageous under 
extreme conditions. Support of these idea comes from the fact that some Colletotrichum species which are pathogenic on the main host species but symptomless endophytes on 'non -disease' host species, providing mutualistic benefits such as disease resistance, drought tolerance and growth enhancement. This differential behaviour may result from differences in fungal gene expression in response to the plant or differences in the ability of the plant to respond to the fungus. Mutualistic endophytes can be evolved from parasitic or pathogenic fungi [13].

Colletotrichum gloeosporioides was a pathogen for long period. The organism interacts with numerous plant species overtly as symptomatic pathogens and cryptically as asymptomatic pathogens. It is not clear whether these contrasting ecological modes are optional strategies expressed by individual Colletotrichum species or whether species ecology is explicitly pathogenic or endophytic. The ecological significance of endophytism is unclear. The genus Colletotrichum (Sordarimycetes, Ascomycota) comprises $~ 600$ species [15]. As per ARS fungal databases, it attacks over 3,200 species of monocot and dicot plants. The infection strategy of this organism is a multistage hemibiotrophy [16]. Colletotrichum gloeospoirioides has been reported to produce taxol [17].

The establishment of endophytic association with plants are interesting, the initial steps being the same - recognition, germination and penetration and then a quiescence stage is developed. There may be some mechanism to avoid recognition also. For example a gene has been cloned from Colletotrichum gloeosporioides which is switched on during the initial phase of colonisation and switched off later during the neurotropic phase [18]. This gene encodes a glycoprotein that resembles plant cell wall proteins which is believed to coat the hyphae that the plant is unable to recognise as alien.

Colletotrichum are endophytes as well as disease agents of conifers [19-23] and ferns [24,25]. They are associated widely with both herbaceous and woody plants, though the latter appear mainly to contain colonies in fruits, leaves and other non-lignified tissues. The generic name Colletotrichum was introduced by Corda [26] for C. lineola, a species found associated with a member of the Apiaceae in the Czech Republic. The first applications of DNA sequence data to distinguish between Colletotrichum species were published by Mills et al. [27] and Sreenivasaprasad et al. [28], who identified sequence variation in the ITS1 region of nrDNA between six species of Colletotrichum, as well as detecting polymorphisms in the same region between strains of $C$. gloeosporioides from different hosts. The biotrophic life strategies adopted by Colletotrichum species may also contribute to their prominence as symptomless endophytes of living plant tissues [21,29-31]. Research into the molecular basis of hostparasite interactions in Colletotrichum is currently highly active and such approaches will dominate research in the future into the extent of host specificity exhibited by Colletotrichum species. Constant monitoring of the tree for disease symptoms are done to check whether the endophyte is transformed to pathogen.

No angiosperms that do not harbour endophytic Colletotrichum colonies are known so far. There are many reports about isolation of taxol, the anticancer drug from Colletotrichum gloeosporioides from different plants [18]. Our aim is to study the therapeutic potential of the fungi isolated from C. travancorica. The phytochemical evaluation is under study.

\section{References}

1. Sieber TN (2007) Endophytic fungi in forest trees:are they mutualist? Fungal Biology Reviews. 21: 75-89
2. Strobel G, Daisy B, Castillo U, Harper J (2004) Natural products from endophytic microorganisms. J Nat Prod. 67: 257-68.

3. Kumara, Patel Mohana (2012) "Fusarium proliferatum, an endophytic fungus from Dysoxylum binectariferum Hook. f, produces rohitukine, a chromane alkaloid possessing anti-cancer activity." Antonie van Leeuwenhoek 2: 323329.

4. IUCN (2011) IUCN Red list of Treatened species. IUCN, Gland

5. Nayar MP, Sastry ARK (1988) Red data book on Indian Plants, Botanical Survey of India. Calcutta.

6. Kharwar RN, Verma VC, Strobel GA, Ezra D (2008) The endophytic fungal complex of Catharanthus roseus (L.) G. Don. Current Science 95: 228-233.

7. Photita W, Lumyong S, Lumyong P, Hyde KD (2001) Endophytic fungi of wild banana (Musa acuminate) at Doi Suthep Pui National Park, Thailand. Mycological Research, 105: 1508-1513.

8. Petrini O (1982) Notes on some species of Chloroscypha endophytic in Cupressaceae of Europe and North America. Sydowia, 35: 206-222.

9. Frohlick J, Hyde KD, Petrini O (2000) Endophytic fungi associated with palms Mycological Research, 104: 1202-1212.

10. White TJ, Burns T, LEF S, Taylor J (1990) Amplification and direct sequencing of fungal ribosomal genes for phylogenetics. In: PCR protocols: A guide to Methods and Application. Academic Press. San Diego, USA. 315-322.

11. Mostert L, Crous DW, Petrini O (2000) Endophytic fungal association with shoots and leaves of Vitis Vinifera with specific reference to Phomopsis Viticola complex. Sydovia 52: 46-58.

12. Saikkonen K (2007) Forest structure and fungal endophytes. Fungal Biology Reviews 2: 67-74.

13. Osono T (2006) Role of phyllosphere fungi of forest trees in the development of decomposer fungal communities and decomposition processes of leaf litter. Canadian Journal of Microbiology 52: 701-716.

14. Promputtha I, Lumyong S, Dhanasekaren V, McKenzie EHC, Hyde et al (2007) A phylogenetic evaluation of whether endophytes become saprotrophs at host senescence. Microbial Ecology 53: 579-590.

15. Crous PW, Gams W, Stalpers JA, Robert V, Stegehuis G (2004) MycoBank: an online initiative to launch mycology into the 21st century. Stud Mycol 50: 19-22.

16. Perfect SE, Hughes HB, O'Connell RJ, Green JR (1999) Colletotrichum, a model genus for studies on pathology and fungal plant interactions. Fungal Genet Biol 27: 186-198.

17. Gangadevi V, Muthumary J (2008) Isolation of Colletotrichum gloeosporioides, a novel endophytic taxol-producing fungus from the leaves of a medicinal plant Justicia gendarussa. Mycologia balcanica 5: 1-4

18. Perfect SE, O'Connell R, Green EF, Doering-Saad C, Green JR (1998) Expression cloning of a fungal proline-rich glycoprotein specific to the biotrophic interface formed in the Colletotrichum-bean interface. Plant J; 15: 273-9.

19. Dingley JM, Gilmour JW (1972) Colletotrichum acutatum f.sp. pinea associated with terminal crook disease of Pinus spp. New Zealand Journal of Forestry Science 2: 192-201.

20. Wang YT, Lo HS, Wang PH (2008) Endophytic fungi from Taxus mairei in Taiwan: first report of Colletotrichum gloeosporioides as an endophyte of Taxus mairei.

21. Joshee S, Paulus BC, Park D, Johnston PR (2009) Diversity and distribution of fungal foliar endophytes in New Zealand Podocarpaceae. Mycological Research 113: 1003-1015.

22. Damm U, Cannon PF, Woudenberg JHC, Crous PW (2012) The Colletotrichum acutatum species complex. Studies in Mycology. 73: 37-113.

23. Leahy R, Schubert T, Strandberg J, Stamps B, Norman D (1995) Anthracnose of Leather leaf fern. Plant Pathology Circular 372: 4.

24. Mackenzie SJ, Peres NA, Barquero MP, Arauz LF, Timmer LW (2009) Host range and genetic relatedness of Colletotrichum acutatum isolates from fruit crops and leather leaf fern in Florida. Phytopathology. 99: 620-631.

25. Corda ACl (1831) Die Pilze Deutschlands. In: Deutschlands Flora in Abbildungen nach der Natur mit Beschreibungen (Sturm, J, ed.). Sturm, Nürnberg vol. 3, Abt. 12: 33-64, tab. 21-32. 
Citation: Pillai TG, Jayaraj R (2015) Colletotrichum gloeosporioides: A True Endophyte of the Endangered Tree, Cynometra travancorica in the Western Ghats. J Plant Pathol Microb 6: 267. doi:10.4172/2157-7471.1000267

26. Mills PR, Hodson A, Brown AE (1992) Molecular differentiation of Colletotrichum gloeosporioides isolates infecting tropical fruits. In: Bailey JA, Jeger MJ (eds) Colletotrichum: Biology, Pathology and Control CABI, Wallingford, UK, pp. 269 288.

27. Sreenivasaprasad S, Brown AE, Mills PR (1992) DNA sequence variation and interrelationship among Colletotrichum species causing strawberry anthracnose. Physiological and Molecular Plant Pathology. 41: 265-281. Botanical Studies 49: 39-43.

28. Lu G, Cannon PF, Reid A, Simmons CM (2004) Diversity and molecular relationships of endophytic Colletotrichum isolates from the Iwokrama Forest Reserve, Guyana. Mycological Research 108: 53-63.
29. Rojas El, Rehner SA, Samuels GJ, Van Bael SA, Herre EA, et al. (2010) Colletotrichum gloeosporioides s.l. associated with Theobroma cacao and other plants in Panama: multilocus phylogenies distinguish pathogen and endophyte clades. Mycologia 102: 1318-1338.

30. Yuan ZL, Su ZZ, Mao LJ, Peng YQ Yang GM, et al. (2011) Distinctive endophytic fungal assemblage in stems of wild rice (Oryza granulata) in China with special reference to two species of Muscodor (Xylariaceae). Journal of Microbiology 49: 15-23.

31. O'Connell RJ, Thon MR, Hacquard S, Amyotte SG, Kleemann J, et al. (2012) Life-style transitions in plant pathogenic Colletotrichum fungi deciphered by genome and transcriptome analyses. Nature Genetics. 